\title{
THINKING WITH DRINKING: WINE AND THE SYMPOSIUM IN ARISTOPHANES*
}

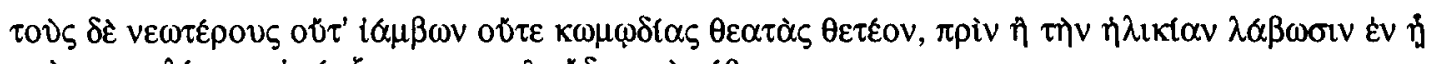

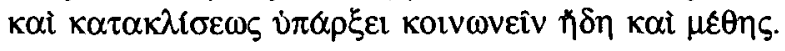

('Young men should not be spectators at recitals of iambic poems or at comedies until they reach the age when they are allowed to take part in reclining and drinking wine.' [Arist. Pol. 1336b20-2])

\section{INTRODUCTION}

The symposium has received much attention recently ${ }^{1}$ but, despite the frequency with which comedy refers to it, ${ }^{2}$ little has been said about its function in this genre. ${ }^{3}$ Pauline SchmittPantel has discussed the public banquets in Aristophanes, ${ }^{4}$ and suggests that 'les banquets "privés" ... sont décrits avec complaisance, sans que leur fonctionnement soit critiqué et que leur existence soit remise en cause ... Les repas publics sont l'objet, par le biais de la distorsion comique, de critiques'. ${ }^{5}$ However, we shall find that the imagery of the symposium is not used in so simple and unproblematic a manner, but is employed in a number of different ways to examine and articulate the questions raised by the dramas: like a myth, the symposium seems to be 'good to think with'. The symposium thus functions in Aristophanic comedy as the symposium did in Greek society, as an institution where values, political and moral, public and

* This article picks up some points in my Aristophanes: myth, ritual and comedy (Cambridge 1993), which can be consulted for further discussion. The following works are referred to by the name of author or editor(s) alone: C. Bérard et al., A city of images: iconography and society in ancient Greece (Princeton 1989); E.L. Bowie, 'Wine in Old Comedy', in Murray and Tecuşan, 113-25; R. Hamilton, Choes and Anthesteria: Athenian iconography and ritual (Ann Arbor 1992); F. Lissarrague, The aesthetics of the Greek banquet: images of wine and ritual (tr. A. Szegedy-Marszak, Princeton 1987); O. Murray (ed.), Sympotica (Oxford 1990); O. Murray and M. Tecuşan, In vino

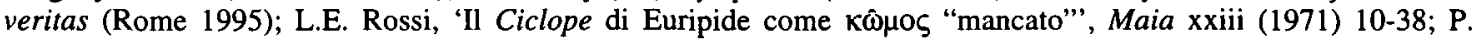
Schmitt-Pantel, La cité au banquet: histoire des repas publics dans les cités grecques (Rome 1992); W.J. Slater (ed.), Dining in a classical context (Ann Arbor 1991); J. Vaio, 'Aristophanes' Wasps. The relevance of the final scenes', GRBS xii (1971) 335-51.

${ }^{\prime}$ Cf. esp. Murray, Murray and Tecuşan, Slater, Schmitt-Pantel. I am grateful for comments to audiences in Durham and Oxford and to JHS's three acute and helpful referees.

2 It is much less frequent in tragedy, though satyr-plays naturally use it: $c f$. e.g. Aeschylus, Ag. 1186-93, 1384-7, 1395-8; ?Cho. 344, Supp. 27, frr. 55 (Epigonoi), 179-80 (Ostologoi; satyr-play?). Sophocles, Ajax 1199 ff., frr. 42(?), 277 (Inachus), 425 (Nauplius), 537 (Salmoneus), 565 (Sundeipnoi; it is possible, but no more, that all these last four plays were satyr-plays), 611. Euripides, Ion 1170-95 (public banquet described, with normal sympotic features), Alc.

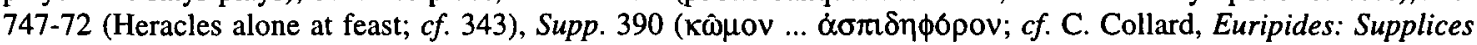

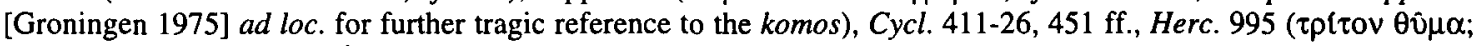
cf. fr. 148 [Andromeda] $\tau \hat{\varepsilon} \lambda \varepsilon l o \zeta$ of third krater), Phoen. 784-800 (Ares and symposium), frr. 562 (Oineus) and 631 (Pleisthenes) both refer to the kottabos. Cf. M.G. Palutan, 'La parodia del cottabo nei $\Sigma u ́ v \delta \varepsilon ı \pi v o r$ di Sofocle e negli

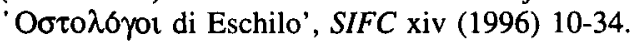

3 An exception is I. Lada-Richards, 'Initiating Dionysus: ritual and theatre in Aristophanes' Frogs' (Diss. Cambridge 1993 = Oxford forthcoming), which obviates the need to discuss Frogs here. I also largely omit the comic fragments, on which Ian Ruffell is working in Oxford; $c f$. also M. Vetta, Poesia e simposio nella Grecia antica: guida storica e critica (Rome 1983) xiii-lx, esp. xlvii, liv-lvii; E.L. Bowie. For later comedy, cf. R.L. Hunter, Eubulus: the fragments (Cambridge 1983) 186: 'The common milieu of the symposium in Middle Comedy perhaps contributed to the increasingly moralising tone of Comedy, since the symposium was traditionally a place for gnomic reflection' (cf. ibid. 22).

${ }^{4}$ Schmitt-Pantel 222-31.

5 224; the distinction is not total: public feasts can take the form of private symposia. 
private, were tested. ${ }^{6}$ Comedy thus employs the symposium just as did archaic lyric, ${ }^{7}$ Plato, ${ }^{8}$ and the historians. ${ }^{9}$ Representations of the symposium and the imagery associated with it are used to structure the plays and their arguments, sometimes through full sympotic scenes, more often through selection of elements from the deipnon-symposium-komos complex, rather as vases will depict different aspects of the symposium in a selective way or suggest location in a particular place or on stage through a symbolic short-hand. This complex, for which, for brevity's sake, I shall often use the terms 'symposium' and 'sympotic', can be sketched for future reference as follows. At the deipnon, food but not wine was taken. ${ }^{10}$ The symposium itself was inaugurated by a libation and tasting of neat wine with the words $\alpha \gamma \alpha \theta 0 \hat{v} \delta \alpha i \mu o v o \zeta$ ('in honour of the Good Daimon');" then three kraters were mixed;', delicacies (tragemata) were served; ${ }^{13}$ hymns and scolia were sung, a myrtle branch being passed from singer to singer $;^{14}$ the equality of the symposiasts was expressed in various ways. ${ }^{15}$ Finally, in the komos, ${ }^{16}$ the symposiasts might go boisterously into the street, accompanied by slaves with torches and perhaps bars, to the house of some attractive person, there to perform the paraklausithyron in the hope of luring them out. Komos, from which comedy derives its name, ${ }^{17}$ was also used of other institutions, such as processions in honour of gods, epinicia, groups of satyrs, and weddings, ${ }^{18}$ echoes of which will also be found in Aristophanes. ${ }^{19}$

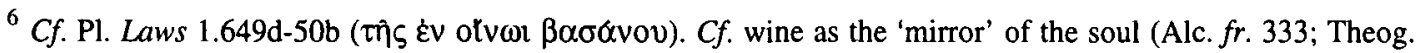
499-500; Aes. fr. 393), and current work on the iconography of drinking vessels (e.g. Lissarrague, Bérard).

7 'The Theognidea describes the polis in terms of a symposium and the symposium in terms of a polis' (D.B. Levine, 'Symposium and polis', in T.J. Figueira and G. Nagy [eds.], Theognis of Megara: poetry and the polis [Baltimore and London 1985] 176); cf. e.g. Theognis 499-502; Solon, fr. 4.9-10.

${ }^{8}$ Though earlier generally critical of the symposium, in Laws $\mathrm{i}$-ii he explores the symposium as a place of testing and education (M. Tecuşan, 'Logos sympotikos' in Murray 238-60); cf. Rep. 7.562c-d, the democratic state's 'thirst' for freedom served by 'bad wine-pourers' too generous with unmixed wine.

9 'Since such entertainments may be seen as a microcosm of society ... a properly conducted symposium or deipnon was an index of civilised behaviour' (G. Paul, 'Symposia and deipna in Plutarch's Lives and in other historical writings', in Slater 166).

${ }^{10}$ For ancient collections of evidence, $c f$. esp. Pollux vi 7-112 and Athenaeus' Deipnosophists; also A. Mau, $R E$ iv (1901) s.v. 'Comissatio' 610-19.

$11 C f$. A.B. Cook, Zeus: a study in ancient religion ii pt. 2 (Cambridge 1925) 1125 n.1, esp. passages quoted

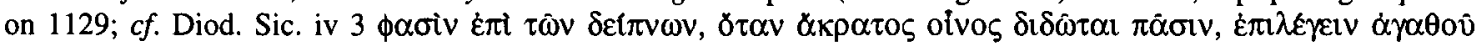
$\delta \alpha\{\mu$ ovos; Plut. Mor. 655e, $735 \mathrm{~d}$-e for use of the phrase before drinking new wine.

12 Dedicated to Zeus and the Olympians, the heroes and Zeus Soter (or Teleius). Cook (n.11), 1123 n. 7 lists the references to the different kraters; cf. E. Fraenkel, Aeschylus: Agamemnon (Oxford 1950) 652-3; Hunter (n.3) 185-9.

${ }^{13} C f$. Athen. 641f and Alexis fr. 190.

${ }^{14} C f$. Dicaearchus fr. $89 \mathrm{~W}\left(=\Sigma^{\mathrm{RVE}}\right.$ Clouds 1364); Ar. frr. 444 and perhaps 235.

15 Vases show this equality by the spatial arrangement of symposiasts around the krater. All seats were equally important; wine was distributed in equal measures, as was food, which is often so represented on vases; each drinker had his turn with the myrtle-branch.

${ }^{16} C f$. Lamer, $R E$ xi (1922) 1286-1304; W. Headlam, Herodas: the mimes and fragments (A.D. Nock [ed.], Cambridge 1922) on 3.34-7; Rossi; F.R. Adrados, Festival, comedy and tragedy: the Greek origins of theatre (Leiden 1975).

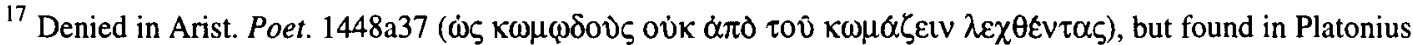
de com. 2.1 (Kaibel, $C G F$ p.7) and later passages in Kaibel pp. 16, 34, 36, 38, 58, 62, 72. This etymology is usually given second place to that from $\kappa \omega \mu \eta$.

${ }^{18}$ The word needs to be related to a wider range of activities in comedy than simply marriage, which was the suggestion of F.M. Cornford in The origin of Attic comedy (Cambridge 1914).

${ }^{19}$ No extant comic chorus is described explicitly as a komos: contrast Eur. Cycl. 39 and Seaford ad loc. Cf.

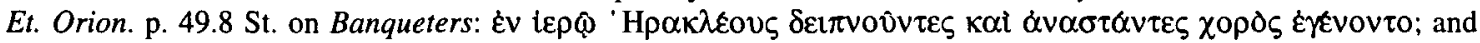

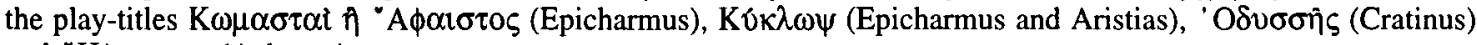

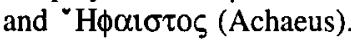


The socio-political role of the symposium in fifth-century Athens is important background to our study, but there is less evidence for it than for the earlier period. The formal symposium seems to have belonged largely to the wealthier classes, ${ }^{20}$ but was not necessarily perceived as inimical to the democracy. The clubs / symposia ${ }^{21}$ were probably not primarily political institutions: "even the hetaireia or the synomosia spent most of its time engaged in sympotic actions, and it was out of these that its political activities "in law cases and contests for office"

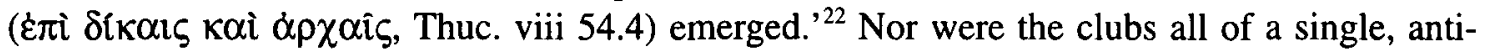
democratic temper: Ath. Pol. 34.3 speaks of clubs of different persuasions at the time of the Oligarchic Revolution, and Thucydides (ibid.) recounts Peisander's attempts to have them act in unison. Calhoun saw the events of 411 as a turning point in people's attitudes to the clubs, ${ }^{23}$ while Murray goes a little earlier, to the time of the Hermocopidae and Profanation of the Mysteries. $^{24}$

Aristophanes' evidence is somewhat problematic. Murray suggests that Philocleon's ignorance of sympotic behaviour ${ }^{25}$ in Wasps shows that 'to the ... audience, the symposion is an alien world of licence and misbehaviour' ${ }^{26}$ But the situation is ambiguous: Bdelycleon can

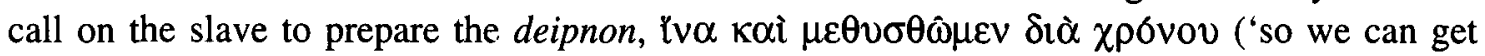
drunk at last', 1252), which suggests sympotic activity was not unknown in that house. A household where an old father knew little of the symposium unlike his more sophisticated son is imaginable, but also at least odd, and the scene may be less a realistic description than a device to foreground crucial oppositions in the play. There is a similar problem with Strepsiades' symposium in Clouds, because of the difficulty of gauging his socio-economic position. Nonetheless, if poorer people spent little time sympotically, the frequency of sympotic imagery in drama suggests familiarity with its features, ${ }^{27}$ and in Aristophanes the symposium is not associated exclusively with any particular social class.

There will be no simple 'totalising' answer to the question of the role of the symposium in Aristophanes: it appears to be an institution that, in whole or in parts, can perform a variety of functions, both structural and analytical. If one had to summarise, one could say that the basic function of the sympotic codes is to chart and so allow evaluation of changes in the comic world, via a shift from abnormal or non-existent sympotic practice to normal activity. It is as

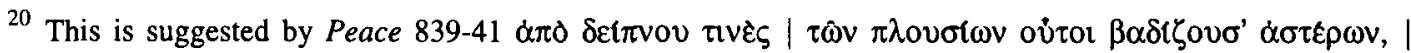

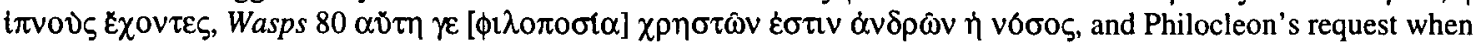

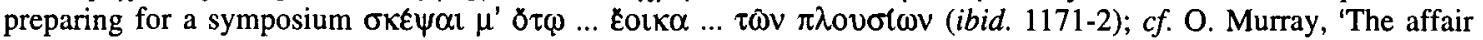
of the Mysteries' in Murray 149-50; Vaio 338-40. Contrary arguments are less convincing, such as E. Pellizer's relying on the 'proliferation of sympotic scenes in vase-painting' (in Murray 181), and G.M. Calhoun's that Pl. Apol. 36b shows most citizens relied on clubs for protection (Athenian clubs in politics and litigation [Austin 1913] 1-2: the other things there mentioned are not such as ordinary citizens would normally have aspired to). To some extent, barbers' shops ('symposia without wine', according to Theophrastus, ap. Plut. Mor. 679a) will have fulfilled the social and alcoholic roles of the symposium for the less wealthy: $c f$. S. Lewis, 'Barbers' shops and perfume shops', in A. Powell (ed.), The Greek world (London and New York 1995) 432-41.

${ }^{21}$ Calhoun (n.20) 5-7 does not list $\sigma u \mu \pi 6 \sigma o v$ amongst the terminology for clubs, but there is no doubt about their sympotic nature.

22 Murray in Murray 150-1; for the last point, cf. Pl. Tht. 173d and Calhoun (n.20) 16.

23 (n.20) 7-9.

24 In Murray 150.

${ }^{25}$ Possibly more apparent than real? Cf. 525, 616-19.

${ }^{26}$ In Murray 150; cf. 151-2 on Andoc. i 37 ff.; also Vetta (n.3) xxxi.

${ }^{27}$ Perhaps from festivals, where they were sympotic themselves or saw elites being so? Philochorus $\mathrm{FGrH} 328$

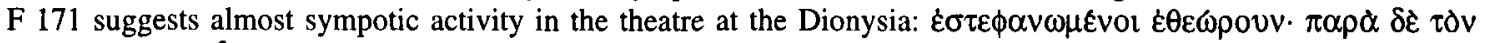

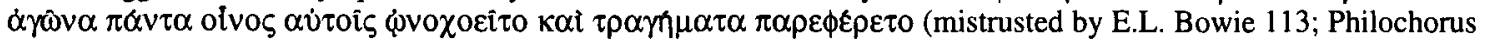
is relying on a passage of the comic poet Pherecrates [fr. 101]). Tzetzes $\Sigma$ Hsd. Op. 368 refers to a kolvov $\sigma u \mu \pi \delta \sigma o v$ at the Pithoigia of 'the Greeks' (mistrusted by Hamilton 8). 
if the natural state of a peaceful and ordered world is an ordered symposium, and the status of characters is indicated through the morality enshrined in sympotic practice: the criterion for judgement is an idealised sympotic practice of balance and restraint, which obviously was not reflected in all actual symposia. At the same time, there are cases where the symposium has less of a normative function and becomes problematic in its own right. For convenience therefore, we shall, perhaps arbitrarily, divide the plays into those where the symposium is involved in analysing social questions and those where it deals with war; in each group there is a play where its function is more complex than in the others. Finally, Ecclesiazusae will allow some reflections on the use of the symposium in comedy generally.

\section{SYMPOSIUM AND SOCIETY}

\section{Clouds}

In the following plays, the symposium is used in various ways to chart the state of relationships, within an oikos or within the polis. In Clouds, abuse of sympotic practice marks the error of Strepsiades' ways, and his return to the straight and narrow involves correct perceptions about things sympotic. To celebrate his son's return from the Phrontisterion, he invites him to dinner, ${ }^{28}$ and at the subsequent symposium the breach between them becomes overt (1354-8 and 1364-7):

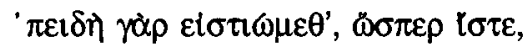

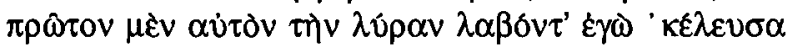

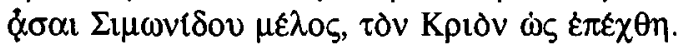

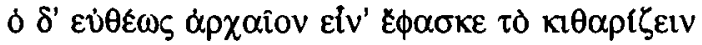

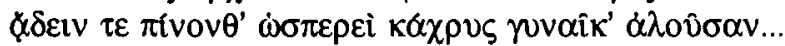

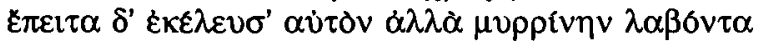

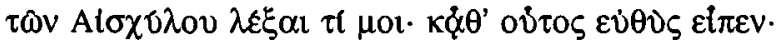

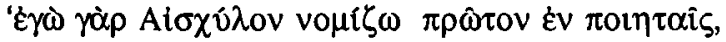

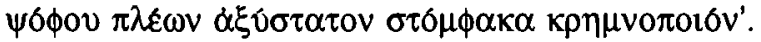

(When we'd dined, as you know, I first told him to take up the lyre and sing Simonides' song of how the Ram was shorn. He replied straightaway that it was old-fashioned to play the lyre and sing when drinking, as if one were an old woman milling parched barley ... Then I told him at least to take the myrtle-branch and sing me something by Aeschylus. Quick as a flash, he said, 'Yes, I think Aeschylus is first among poets- for bombast, uncouthness, turgidity and big words'.)

The new philosophy thus disrupts traditional ways not only of thinking but also of social intercourse at the symposium..$^{29}$ As a result, brawling breaks out, the negation of the proper

28 For such celebratory deipna, cf. C. Daremberg and E. Saglio, Dictionnaire des antiquités grecques et romaines (Paris 1904) 1597. Parenthetically, one might suggest that such 'reintegration' may explain Pheidippides' reference to the Protenthai (1198-1200), officials equivalent to the later Progeustai who checked the food for festivals according to Athen. (171c-e; $c f$. also Pherecrates fr. 7; Aelian, $N A$ xv 10, fr. 39; the verb is not found again until Eustath. 1202.3). In fifth-century Athens, they were probably especially connected with the Apaturia ( $c f$.

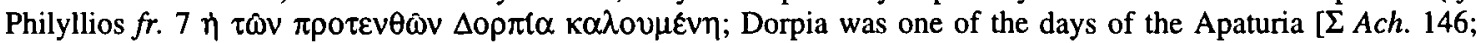
Hsch. $\alpha$ 5842]). Does mention of these officials and the coining of a verb from their name draw attention to the Apaturia when fathers inducted sons into their phratries, and thus provide an ironic background for the dinner marking the son's return?

${ }^{29}$ Cf. Dover on $1353-90$. 
symposium's balanced and civilised behaviour. ${ }^{30}$ The collapse of relationships within the oikos is figured through the collapse of the symposium.

Furthermore, between the invitation (1212) and the catastrophic symposium, come two scenes with creditors: this framing is significant. The dinner is to celebrate Strepsiades' freedom from his obligations to society, specifically his debts. In fact, it marks the isolation of the two symposiasts from the rest of their society (vinously rejected as 'piles of amphoras' [1203]) in two ways, both through the sympotic isolation of father and son, and through the rough expulsion of a fellow-demesman (1219). A symposium 'à deux' was possible, for instance on special occasions such as attempted seduction, ${ }^{31}$ but the refusal to invite others at such a celebratory time is strange, as the contrast with, say, Xuthus' reaction to the discovery of his

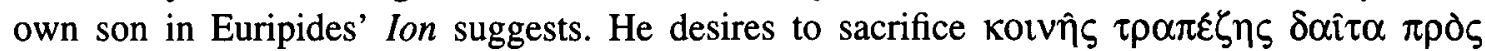

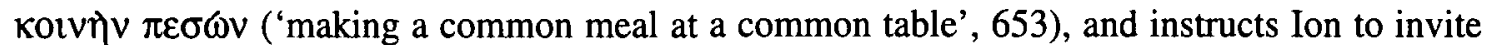

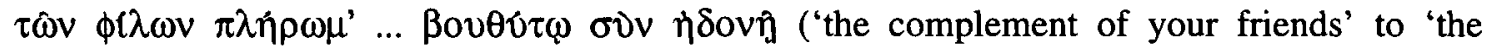
pleasure of a sacrifice', 664-5). The danger of Strepsiades' isolation is vividly brought home to him when, assaulted by his son, he is forced to appeal for protection to precisely those despised 'neighbours, kinsmen and fellow-demesmen' (1322) whom he has treated with such scorn and violence and excluded from his social life. The value of such ties, even though they may entail debts, is made manifest by this juxtaposition of an exclusive symposium with a demonstration of the usefulness of friends when things go wrong.

At the end, Strepsiades speaks to the dinos that stands outside the Phrontisterion (1473), and to the statue of Hermes (1478), god of human commerce, that stands outside his own house. Whether the dinos is a cup or a mixing-bowl, ${ }^{32}$ either would symbolise the symposium, so that these two fixtures stand for the world of vinous and social mixing that Strepsiades tries to leave along with his debts (which in part constitute that mixing) for the isolation of the philosophy schools, where you were lucky to get any dinner at all $(175-9,186)$. His return to a correct perception of the sympotic dinos, after its Socratic perversion into a new-philosophical cosmic principle (1473-4), along with his burning of the Phrontisterion, restores a kind of normality to Athens. Unsocial symposia and the misuse of sympotic items bring their own reward.

${ }^{30}$ Cf. e.g. Theognis 467-96; Alexis fr. 160; Plut. QC 629e-34f; Levine (n.7) 180-6; E.L. Bowie, 'Greek tabletalk before Plato', Rhetorica xi (1993) 355-73. For 'balance' in the symposium, $c f$. Lissarrague 68-80. For the terms used of good and bad symposiasts, $c f$. Pollux vi 28-9.

${ }^{31}$ Pl. Symp. $271 \mathrm{c} 7$ ff. In Plut. Ant. 70.3-4 a symposium of two is thought pleasant by one misanthrope, but a crowd by Timon.

32 In a comedy, it is hard to be certain, but a round-bottomed, handleless dinos, probably like the lebes on a stand, might seem on balance a slightly less unusual item than a large cup to stand outside a house. Much of the terminology of vase-names was laid down in the last century and usage in antiquity can be ambivalent. G.M.A. Richter and M.J. Milne, Shapes and names of Athenian vases (New York 1935) 9-10 argue against the use of dinos for the shape lebes and in favour of its being a cup. In Ar. Wasps $616 \mathrm{ff}$. and Pollux vi 96 it certainly is a cup; in

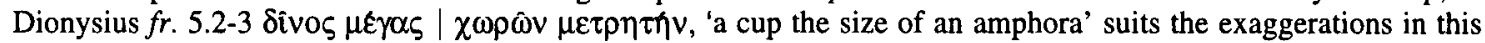
description of an old woman's fondness for cups ( $c f$. Hsch. 8508); in Philyllius fr. 6.1 where a dinos is addressed as ' $\alpha \mu \phi \circ \rho \varepsilon \hat{0}$ ' it could refer to a larger vessel, unless there were a similar joke to that in Dionysius. However, in

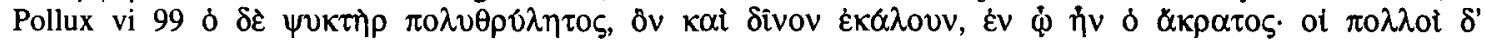

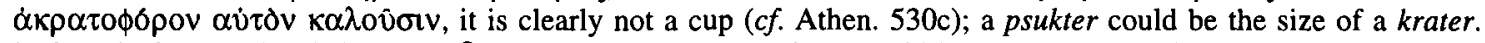
In Strattis fr. 35, a head similar to $\delta$ iv $\varphi \pi \varepsilon \rho \iota \kappa \alpha \tau \omega ~ \tau \varepsilon \tau \rho \alpha \mu \mu \varepsilon v \omega$ would have more comic force if it referred to the round bottom of the large lebes (for which $c f$. Pollux l.c. and $\Sigma$ Wasps 618d) rather than a round-bottomed cup (cf. Birds 806). For a discussion of the dinos as an old form of the krater, cf. H. Gericke, Gefäsdarstellungen auf griechischen Vasen (Berlin 1970) 36-42. Cf. also, though they do not clarify matters, $\Sigma^{\mathrm{vel}}$ Clouds 381,$1473 ; \Sigma^{\mathrm{Th}-\mathrm{Tr}}$ Clouds 380; Athen. 467d-f. 


\section{Knights}

In Knights, the state of symposiastic practice in Demos' oikos is a metaphor for the state of public affairs in Athens, and the basic shift is from anomalous persons involved in sympotic activity to greater normality. There are four main passages which are structured around the institutions of the symposium. The first is Demosthenes' account of Demos' solitary dining (4070). The various elements of an evening's dining are present in 50-2:

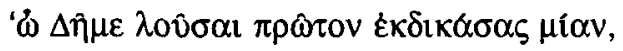

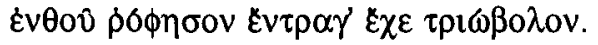

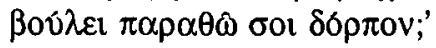

('Demos, have a bath once you've got a single case out of the way; pop that into your mouth; slurp up this; have dessert; take the three obols. Do you want me to bring you your snack later?') ${ }^{33}$

In the absence of guests and with the other slaves kept at bay, Paphlagon exercises control over his master, rather as their isolation enabled Pheidippides to treat his father as he wished. A Paphlagonian slave dominating his Athenian master at dinner acts as a clear image for the state of politics in Athens.

This description of solitary sympotic activity is then repeated on stage in a parallel scene of anomalous sympotic behaviour, involving a slave-symposium. The two slaves, despairing of ever escaping Paphlagon, seek the bravest way of dying. Rejecting imitation of Themistocles'

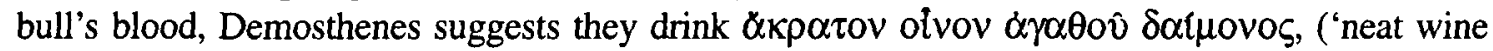

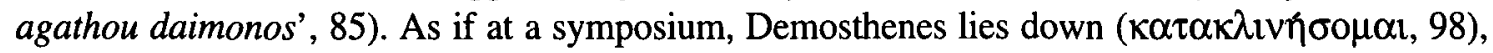
having praised wine in traditional sympotic terms (924):

\section{$\delta \rho \hat{\alpha} \zeta, \delta \tau \alpha \nu \pi i v \omega \sigma \nu \alpha v \theta \rho \omega \pi 01, \tau \delta \tau \varepsilon$

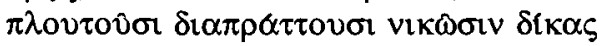

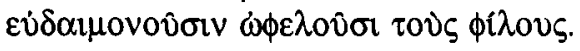

(You see, whenever men drink, they become rich, they are successful, they win their law-suits, they are happy, and help their friends).

Nicias steals wine from Paphlagon, who is asleep and $\varepsilon \pi i \pi \alpha \sigma \tau \alpha \lambda \varepsilon \hat{l} \xi \alpha \varsigma \ldots \mu \varepsilon \theta \tilde{\sigma} \omega \nu$ ('drunk, after licking his epipasta', salt relishes eaten at the symposium, 103-4).$^{34}$ Demosthenes calls for a healthy libation of neat wine, which normally inaugurated the symposium, and as a result, ${ }^{35}$ the 'good daimon' gives Demosthenes the idea which will bring salvation to the slaves and to Athens (106-8):

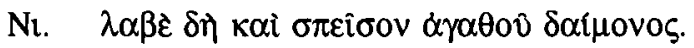

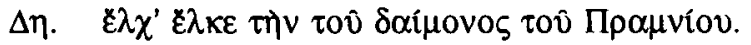

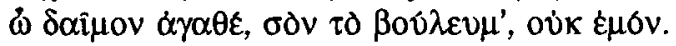

(Ni. Take this and pour a libation agathou daimonos. De. Drink deep, drink deep of the Pramnian god. O agathos daimon, the idea is yours not mine. $)^{36}$

${ }^{33}$ For $\varepsilon v \tau \rho \alpha \gamma$ ', 'used only of eating $\tau \rho \alpha \gamma \eta \mu \alpha \tau \alpha$ ', and $\delta 6 \rho \pi \circ \nu$ of a post-sympotic feast, $c f$. Neil on 51 and 52. There may also be a double pun in $\beta v \rho \sigma i v \eta v$, pointing to $\mu \nu \rho \sigma i v \eta v$, a fly-swatter (only Martial iii.82.2, in fact), and also perhaps the branch held by the symposiast.

${ }^{34}$ Cf. Pherecrates fr. 137.3; Plut. QC 669b.

35 This was a significant moment: in Eur. Ion 1032-3, the poison is put in the cup at this point.

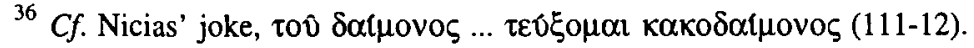


Slaves drinking sympotically is anomalous, and the anomaly is greater, first because Demosthenes' repeated demands ${ }^{37}$ for neat wine mean more goes down his throat than was customary at such libations, and secondly because he is drinking alone. ${ }^{38}$ Gods might enjoy solitary symposia, as they do regularly on vases, and Heracles does so in Alcestis 747-72, but even Euripides' Cyclops finds it strange that he should not share his wine with his brothers. ${ }^{39}$ Amongst mortals, the monophagos was an oddity, and such individual 'symposia' hardly counted as proper occasions. ${ }^{40}$

Sympotic imagery recurs through the play, ${ }^{41}$ but we pass to its next major structural occurrence, where Demos presides 'on the Pnyx' over the contest of gifts proffered by Sausage Seller and Paphlagon. It is through a symposium that Demos' restoration to his better past is effected. He still dines alone, but things have improved now that the tyrannical Paphlagon has been challenged by a potential saviour, and the slaves have returned to their function as servants. The final stage will be reached only when Demos is himself reintegrated into proper social living. At $1161 \mathrm{ff}$, the gifts become ones to do with food. ${ }^{42} \mathrm{~A}$ chair and table are brought out, and, as Neil noted, 'they set out food in something like the natural order of a dinner' ${ }^{43}$ soup and bread are followed by fish and meat; the similar pattern in the second part of Wasps may be compared. Then the ultimate victor brings the wine (1187), 'mixed three to two', a recommended measure for the symposium, and this is followed immediately by the tragemata, a rich cake and a hare. It is at this moment when deipnon becomes symposium that the Sausage Seller has the idea of the crucial theft of the hare, and finally triumphs by demonstrating that his 'dinner-box' is empty because he has given everything to Demos.

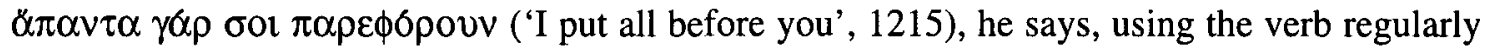
employed of the tragemata. ${ }^{44}$ Paphlagon's unsympotic behaviour in not sharing his food (1218$23)^{45}$ brings his downfall, and the garland passes to his rival (1227-8). ${ }^{46}$

The chorus then dilates on improper and disordered habits at table, the hunger of Thoumantis (1264-73) and the greed of Cleonymus (1291-8); and in between it castigates Ariphrades for 'corrupting his tongue with shameful pleasures' (1284), expressing the hope that anyone who

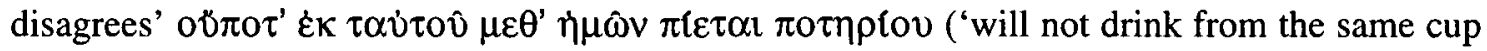
41-2.

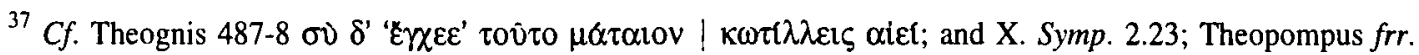

${ }^{38}$ Discussing the end of Acharnians, E.L. Bowie 114 suggests that one-man symposia are in part a function of the restrictions of the theatre, but that does not mean they cannot have the kind of significance given above.

${ }^{39}$ Eur. Cycl. $530 \mathrm{ff}$.

${ }^{40} C f$. O. Murray, 'War and the symposium', in Slater 84 for solitary drinking as generally unknown in many

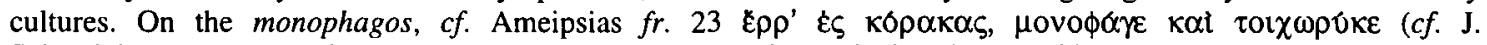
Schweighaeuser, Animadversiones in Athenaei Deipnosophistas i [Strasbourg 1801] 330-1); Antiphanes fr. 291

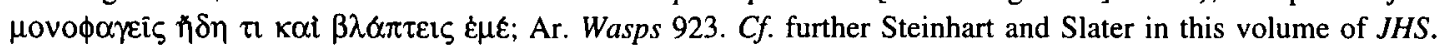

41 E.g. the Chalcidian $\pi$ othplov (237) is evidence of fomenting a revolt amongst the Euboeans; improper enjoyment of the Prytaneum symposia is regularly held against Paphlagon $(281,709,766 ; c f .535-6$ on Cratinus); only Cratinus' songs could be sung Év $\xi u \mu \pi o \sigma(\omega$ (529). On food and politics in the play, $c f$. D.E. O'Regan, Rhetoric, comedy and the violence of language in Aristophanes' Clouds (Oxford 1992) $60 \mathrm{ff}$.

42 'The scene is suggested by the banquet given to the citizens of Athens at the Panathenaea' (Neil on 1168-9), but his commentary shows the deipnon / symposium is a more powerful schema.

${ }^{43}$ Neil on 1166-7, quoting Pherecrates fr. 113; Frogs 504-11.

44 Athen. 380d; Pollux vi 55; cf. Neil ad loc.

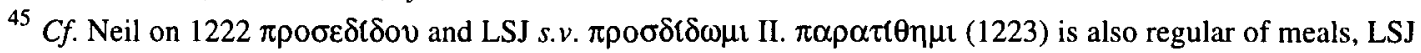
s.v. I.1.b, II.1.

${ }^{46} 1225$ may come from Eupolis' Helots (cf. A.H. Sommerstein, $C Q \times x x$ [1980] 51-3), from which we have a

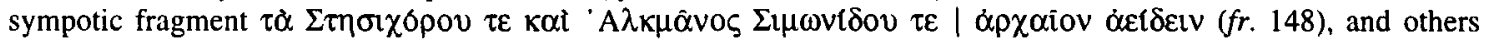
referring to eating and culinary equipment. 
as me', 1289). This reinforces the message of the previous scene that abuse of sympotic practice leads to punishment.

In the final stage, Agoracritus is given new clothing and invited into the Prytaneum, to take the place of Paphlagon (1404-5). With them go the Spondai, perhaps like the hetairai at an aristocratic symposium. In the Prytaneum, the city entertained at civic symposia distinguished men, Athenian and other. ${ }^{47}$ The privilege was much more rarely granted in the fifth century than later, so this is a signal honour. Those who dined there by right were few: victors in the four main games, the Eleusinian Hierophant, the descendants of the tyrannocides Harmodius and Aristogeiton, and 'people chosen by Apollo' ${ }^{48}$ The entertainment, referred to as a $\delta \varepsilon i \pi v o v$ in the case of citizens, ${ }^{49}$ would have included the traditional symposium. Seated together at the city's symposium, Agoracritus and Demos, the latter refreshed, anointed and in new clothes as when he dined ( $\xi \cup v \varepsilon \sigma i \tau \varepsilon l, 1325)$ with Miltiades and Aristeides, thus restore normality to the sympotic imagery of the play and to the political system of the city. No longer confined to his house and under the control of the Paphlagon, Demos is now in sympotic splendour at the city's heart. Paphlagon too ends in a way more appropriate than he began: following Agoracritus' former trade (1400-1),

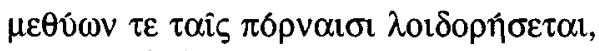

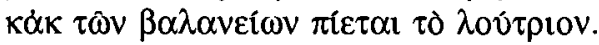

(He will quarrel drunk with the prostitutes, and drink the water from the baths.)

Still drunk and quarrelling with those around like a poor symposiast, he has a liquid more appropriate to his new lowly status. The anomalies of the start of the play are thus reversed, and the four sympotic passages have marked a gradual amelioration in both symposium and city.

\section{Wasps}

In Wasps, from its relationships with the other structuring features of the play, the symposium takes on a negative aspect that it has not had in these first two comedies. ${ }^{50}$ The play opens with fragmented elements of a sympotic discourse, again involving slaves. Two slaves are possessed by sleep 'from Sabazius', a divinity connected with Dionysus (9-10), ${ }^{51}$

${ }^{47}$ S.G. Miller, The Prytaneion: its function and architectural form (Berkeley, Los Angeles and London 1978); R.E. Wycherley, The Athenian Agora iii (Princeton 1957) 166-74; Schmitt-Pantel 145-77; P.J. Rhodes, A commentary on the Aristotelian Athenaion Politeia (Oxford 1981) 308; A.S. Henry, Honors and privileges in Athenian decrees (Hildesheim, Zurich and New York 1983) 262-90; P. Gauthier, Les cités grecques et leurs bienfaiteurs, BCH Supp. xii (Paris 1985). For the possible importance of the Prytaneum to drama, $c f$. C. Sourvinou-Inwood, 'Something to do with Athens: tragedy and ritual', in R.G. Osborne and S. Hornblower (eds.), Ritual, finance, politics: Athenian democratic accounts presented to David Lewis (Oxford 1994) 269-90.

48 These people are connected with the aristocratic past of the city. The other form of public entertainment, a product of the democratic state, took place in the tholos, where architecture and entertainment suggested rejection of the Prytaneum's more aristocratic form (there was no symposium). $C f$. Schmitt-Pantel 145-77; F. Cooper and S. Morris in Murray 66-85.

${ }^{49} C f$. Henry (n.47) $271-5$ for the terminology; in the case of foreigners it is referred to as $\xi \hat{\varepsilon} v i \alpha$.

${ }^{50}$ Cf. Vaio 335-51. The symposium may also have had negative connotations in Banqueters: cf. esp. frr. 225, 232; A.C. Cassio, Aristofane: Banchettanti $(\Delta \alpha \mathrm{\tau} \tau \alpha \lambda \hat{\eta} \varsigma)$ : i frammenti (Pisa 1977); H. Lind, Der Gerber Kleon in den Rittern des Aristophanes (Frankfurt 1990) $141 \mathrm{ff}$.; W. Rösler, 'Mnemosune in the symposion', in Murray 236.

${ }^{51}$ Cf. W. Burkert, Greek religion: archaic and classical (tr. J. Raffan, Oxford 1985) 420 n.32; K-A on Ar. fr. 578. 
and play a sympotic game of riddles ( $\gamma p \hat{i} \phi o \zeta, 20)$ with their dreams, ${ }^{52}(21-3)$ :

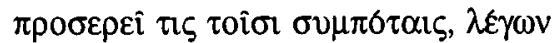

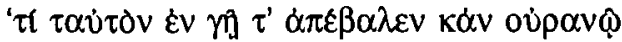

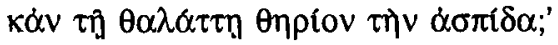

(Someone will say to the symposiasts, 'what beast threw away its shield alike on earth, in heaven and at sea?')

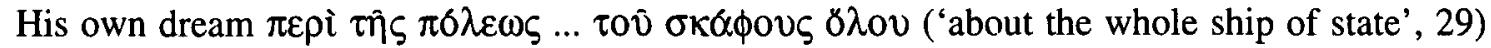
employs a favourite image of sympotic literature and iconography, by which the symposium is imagined as a ship..$^{33}$ As in Knights, the motif of slaves unusually in a sympotic context is indicative of an unsatisfactory situation in the house.

The sleep of the slaves recurs after Philocleon's initial attempts to escape (212-13), and heralds the return of sympotic material in the parodos. This choral entry is in effect a parody of a komos. A group of poor old jurors, guided by awkward sons with feeble lamps, have risen early in the morning (and may go without their deipnon, 311), and are processing to the door of a friend there to sing a song to entice him out. This reverses the pattern of well-fed young men boisterously coming late at night from dinner, accompanied by able-bodied slaves with flaming torches. There are also notable details. The first chorister addressed has the sympotic name 'Comias' (230): it is not usual for choristers to have such names. ${ }^{54}$ Philocleon's amoebean reply parallels the kind of language used when the loved one is forbidden exit, like the Young Girl in Eccles. $952 \mathrm{ff}^{55}$ The songs of Phrynichus $(219-20,269)$ make more sense in a 'sympotic' than a legal setting, ${ }^{56}$ and indeed they will reappear in the sympotic-comastic finale $(1490,1524)$. Recollection of youthful exploits (231-9) is also a feature of sympotic behaviour that Philocleon will learn later (1197 ff.). ${ }^{57}$ Even the aulos accompanying their entry was also the chief instrument of the komos. ${ }^{58}$ The subsequent violence of the chorus' attack

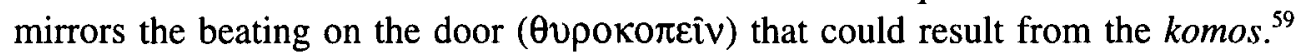

This parody of a komos embodies an implicit opposition between old juror and young symposiast, which is paralleled by the conflict between the father, who mistrusts drink, and the son who regrets the absence of symposia in the home (1253-5). Philocleon complains of his son (340-1):

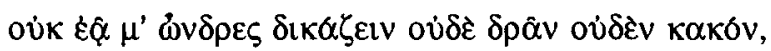

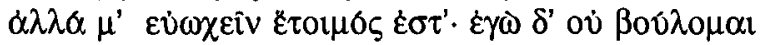

(He won't let me go to the courts or do any harm: he's ready to entertain me, but I don't want it.)

52 For riddles at the symposium, cf. e.g. Hsd. frr. 266-8; Theognis 681-2; Wasps 1308-13; Pl. Symp. 215a; Clearchus fr. 63, I Wehrli; Pollux vi 107-8; G. Monaco, Paragoni burleschi degli antichi (Palermo 1963); M.L. West, Studies in Greek elegy and iambus (Berlin 1974) 17 n.26; Vaio 340 n.24. For this type of witticism, cf. e.g. Wasps 1225-48, 1308-21; Xen. Symp. 2.14, 20.

${ }^{53}$ Cf. Lissarrague 107-22.

54 The other names in 230-4 are not sympotic; cf. 'Pheredeipnos' beside three non-sympotic names in 401; 'Comarchides' in another sympotic passage in Peace 1142.

${ }^{55}$ Cf. C.M. Bowra, AJP lxxix (1958) 376-91.

${ }^{56}$ For tragic songs at the symposium, cf. e.g. Clouds $1365 \mathrm{ff}$.

${ }^{57}$ It is a comastic feature also of the parodoi of Acharnians (211-18) and Lysistrata (271-85).

${ }^{58}$ Cf. Pratinas TGrF 4 F 3.4-9; Theognis 825-30; Pl. Symp. 212d; etc. (cf. F.O. Copley, Exclusus amator; a study in Latin love poetry [Madison 1956] $145 \mathrm{n.10}$ ).

${ }^{59}$ Cf. Copley (n.58) 148 n.26. 


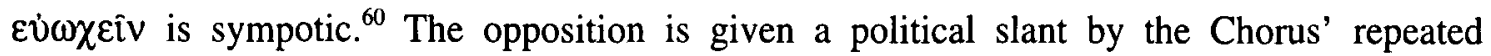

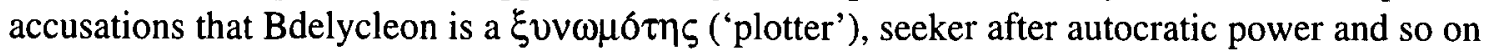
(345, $461 \mathrm{ff}$.). When Bdelycleon bemoans the regularity of such accusations, the examples he gives are ones where desire for certain foods is seen as a sign of tyrannical ambitions (488 ff.). Food and the symposium articulate the play's issues.

The subsequent section of the play, down to the parabasis, is less obviously sympotic, but there remain attenuated sympotic and 'deipnic' aspects. Asked what penalty he will pay if he does not abide by the result, Philocleon says (525):

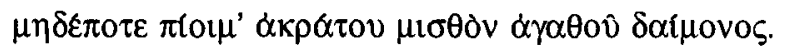

(May I never drink a payload of neat wine agathou daimonos again!)

The unusual entertainment offered in court-Aesopic stories, jokes, tragic recitation, and fluteplaying (566-7, 579-82)--is sympotic, ${ }^{61}$ and this part ends vinously with Philocleon's winevessel farting martially at Bdelycleon's cup ( $\delta$ tvov, 617-18). The sympotic schema is even more attenuated in the trial but still present: Philocleon continues to eat, and the charge is one of eating alone; the voting jars are arustichoi (855), jugs for drawing wine. ${ }^{62}$

However, the sympotic returns strikingly when Bdelycleon gets his wish to educate

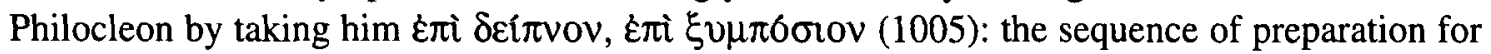
and attendance at a symposium structures the action. Philocleon is dressed, and taught to walk like the rich, relate appropriate tales (1174 ff.) and adopt the correct posture for lying down as

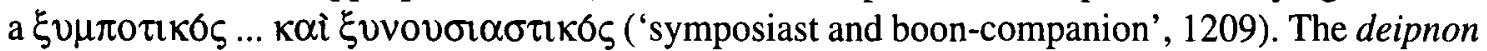
is imagined $(1216-17,1219):^{63}$

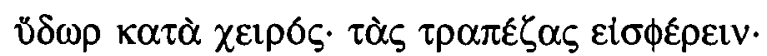

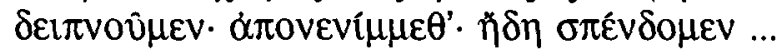

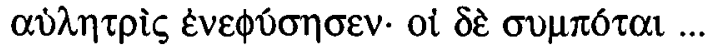

(Water for our hands! Bring on the tables! We're dining; we've washed our hands; now we're making the libations ... the flute-girl has started to play, and the symposiasts are ...)

Philocleon is instructed how to take up a song from his neighbour, or to reply suitably to a quotation given by another. After the practice, a real meal is prepared (1250-2) and they leave for dinner at Philoctemon's. ${ }^{64}$ Philocleon's behaviour at the dinner (1299-1325) is that of one who breaks all the conventions of civilised sympotic behaviour. He defeats all attempts to control him by sympotic jesting, and having removed the torch and flute-girl sets off drunkenly on an especially rowdy solo komos, where violence is offered to passers-by. ${ }^{65}$

The question remains of how this sympotic ending relates to the theme of law-courts and justice, which has been central to the first two-thirds of the play. The following exchange

${ }^{60}$ E.g. Alc. fr. 70.5 LP; Lys. 1224, Eccl. 716-17.

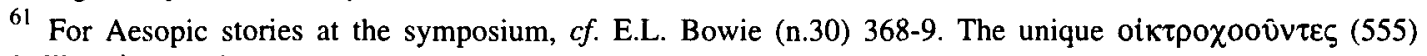

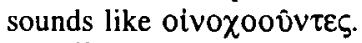

${ }^{62}$ Athen. 424b-c.

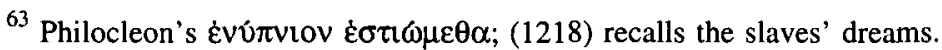

64 For the personnel, $c f$. I.C. Storey, Phoenix xxxix (1985) 317-33; Vetta (n.3) 117-31.

65 Vases regularly show symposiasts carrying sympotic items through the streets. Vaio 345 n.47 relates Philocleon's dancing to the symposium, but he has already left the party. On $\alpha v \varepsilon \chi \varepsilon \pi \alpha \rho \varepsilon \chi \varepsilon(1326)$ and the komos, cf. Seaford on Eur. Cycl. 203. 
suggests an answer. Philocleon expresses his fears about the troubles wine can bring (including the characteristically comastic $\theta 0$ poко $\pi \hat{n} \sigma \alpha$, 'beating on doors', 1254), and Bdelycleon replies (1256-64):

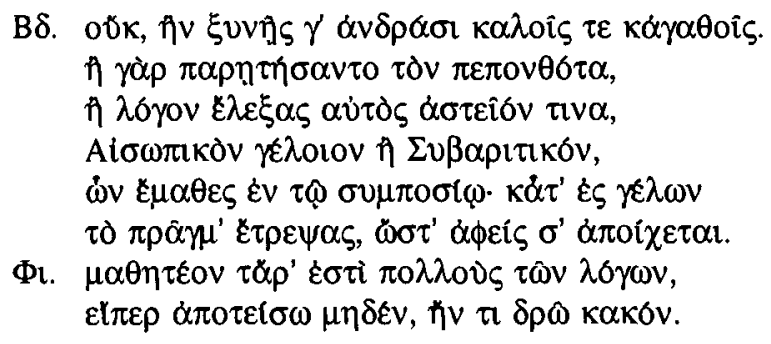

( $B d$. There's no problem, so long as you consort with gentlemen, because either they beg off the man you've insulted, or you yourself tell some amusing story from Aesop or Sybaris, of the sort you've learned in the symposium, ${ }^{66}$ then you turn the thing into a joke, so that he lets you off and leaves you alone. $P h$. Well, I'd better learn lots of those stories, if I can pay no penalty when I've done wrong!)

This symposium thus acts as a potential third main locus of justice in the play, after the city's law-courts, comically discussed in all their horror in the first part, and the domestic trial, an opposite kind of justice dispensed by a single judge. We have in effect three possible types of justice - the democratic, the monarchical and the oligarchic-juxtaposed in a manner reminiscent of Hdt. iii 80-2.

In this third kind, certain members of society arrange freedom from legal sanction for

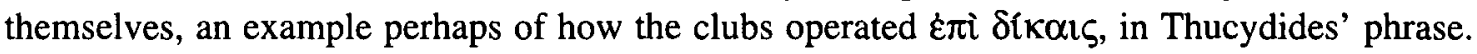
We see this in action when Philocleon replies to Bdelycleon's threats of a case brought by the Bread-Seller (1393-5):

\footnotetext{
ov่ $\alpha \mu \omega \hat{\varsigma} \gamma^{\prime}, \dot{\varepsilon} \pi \varepsilon \grave{\imath}$

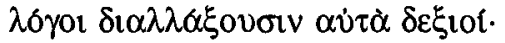

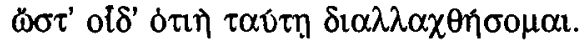

(No, I'll have no trouble, because clever words will sort that out; so I'm sure I'll come to an arrangement with her.)

He then proceeds to tell her Aesopic and other such stories, as he does to the next man who arrives with a witness. His son attempts to beg off those who would prosecute his father (141920): his praise of the legal benefits of being a symposiast returns to haunt him. It is up to the audience whether they prefer the Athenian law-courts as a judicial system, or the private courts of senile judges, or the personal arrangements of drunken symposiasts.

The symposium is thus again structural to the whole play. After the slaves' symposium has marked the abnormality in the oikos, two comastic scenes frame the main action of the play and prompt comparison between themselves. The first ends in ignominious defeat for the comasts, the second in scorn for and apparent freedom from the laws. The latter may represent the triumph of the 'little man', but from a polis perspective is less attractive, and the spectator is left to ponder whether, despite the fact that the Attic wasp is as little controllable in court as in a symposium, the legal processes of the city may not be better served by the harsh frugality of the former 'comasts' than by the sympotic excesses of a few real ones.

${ }^{66} C f$. 566 for such tales used to ingratiate defendants with the jurors; also 1401, 1446; Vaio 342-3. 


\section{SYMPOSIUM AND WAR}

In three plays, the restoration of peace is articulated through the restoration of sympotic enjoyment. In archaic art and literature, the symposium is both complementary to war $^{67}$ and opposed to it. ${ }^{68}$ In comedy, the two are usually opposed: the symposiast fighting for his particular cause alongside his companions from the drinking group is no longer a dominant aspect of social existence, and the symposium comes to symbolise the liberation from war for everyone. The opposition is seen at its simplest in Peace, which does not need detailed analysis. When the vinously named Trygaeus ${ }^{69}$ and his $\kappa \alpha v \theta \alpha \rho \circ \zeta$ (also the word for a drinking vessel especially associated with Dionysus himself ${ }^{70}$ have brought Peace back, a symposiastic celebration of her hidrusis and marriage to Trygaeus is prepared: the hideous monophagia of the Beetle is replaced by preparations for communal feasting. War and the symposium are repeatedly contrasted, in a parabatic chorus (1127 ff.), in subsequent scenes where weapons are turned into sympotic paraphernalia, such as the kottabos (1191 ff.), ${ }^{71}$ and in a scene with the sons of Lamachus and Cleonymus and their more or less appropriate sympotic songs. By contrast, the absence of the sympotic motif from the wedding at the end of Birds is perhaps an indication that Peisetaerus' world is not one of equal participation in a symposium, but a tyranny where sharing has no place. ${ }^{72}$ Other plays use the symposium in more complex ways.

\section{Lysistrata}

Here too the play is framed through symposium and komos, moving from abnormality to ordered celebration of peace. The women's actions are inaugurated by wine (181 ff.): their assumption of control over areas of male dominion involves seizing the initiative not just in matters sexual and political, but also sympotic. Citizen women, like slaves, at the symposium is a social anomaly. ${ }^{73}$

Eschewing complete imitation of the oath sworn over a black shield in Aeschylus' Septem (42 ff.), Lysistrata gives these orders (195-7):

$\theta \varepsilon i \sigma \alpha \imath \mu \varepsilon \lambda \alpha \imath v \alpha v \kappa \tilde{\lambda} \lambda \iota \kappa \alpha \mu \varepsilon \gamma \alpha \lambda \eta \nu$ i $\pi \tau i \alpha v$,

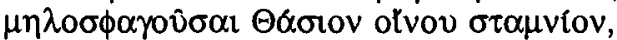

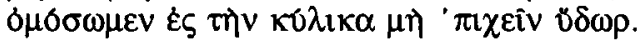

(Put a large, black drinking-cup face-upwards on the ground, and when we've sacrificed a stamnos of Thasian wine let's swear not to pour water into the cup.)

${ }^{67}$ Schmitt-Pantel 17-31. For sympotic and military activity compared, cf. Pl. Laws 1.640-41a, 2.670c8-75c7; Plut. Aem. Paul. 28.5, Mor. 615e-f; Polyb. xxx 14; Athen. 2f, 47e; Tecuşan in Murray 254-5.

${ }^{68}$ Cf. W.J. Slater, ICS vi (1981) 205-14, esp. 211 n.5 (add Eur. Phoen. 784-800); E.L. Bowie 122-5.

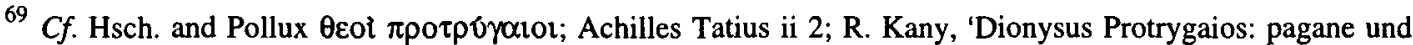
christliche Spuren eines antiken Weinfestes', JbAC xxxi (1988) 5-23.

70 'Er erscheint fast ausschliesslich auf Vasenbildern des Dionysischen Bereiches', (Gericke [n.32] 22; cf. 3642). For another pun on this word $c f .143-5$.

71 1242-4. In 1246-9, until Trygaeus mentions weighing, there is another sympotic resonance: $\pi \lambda \alpha \sigma \tau \gamma \xi$ could again refer to the scale-pan, placed, in other versions of the game, above a statue of Manes, and made to descend to strike his head by wine thrown by the player. On the kottabos, $c f$. K. Schneider, $R E$ xi (1922) s.v. 'Kottabos' 1528-41; B.A. Sparkes, Archaeology xiii (1960) 202-7; E.K. Borthwick, JHS lxxxiv (1964) 49-53; R.M. Rosen, $C Q$ xxxix (1989) 355-9; Lissarrague 80-6; Hermippus fr. 48; Antiphanes fr. 57; Athen. 665a-68f; and Pollux vi 109-10 for different types (summarised by Rogers on 1244).

${ }^{72}$ On a possible sympotic motif at the start, $c f$. R. Hamilton, GRBS xxvi (1985) 235-9.

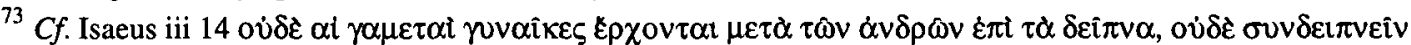

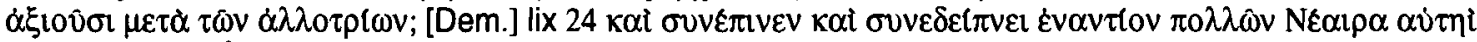

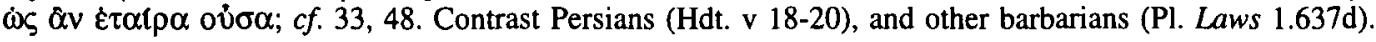


The kulix was the regular sympotic cup, ${ }^{74}$ and Lysistrata addresses it as the loving-cup ( $\kappa 0 \lambda \mathrm{l} \xi$ $\phi 1 \lambda o \tau \eta \sigma i \alpha, 203)$, sharing in which expressed the unity of the symposiasts. ${ }^{75}$ Its substitution for the similarly shaped shield, ${ }^{76}$ which is judged inappropriate to a rite for peace (189-90), marks the start of their work for harmony. This substitution has the same significance as the sympotic transformations of weapons in Peace or Dicaeopolis' sympotic treatment of Lamachus' shield.

The oath-swearing provides a dual portrayal, positive and negative, of the women's actions. First, there is a collision of ritual codes: at a Greek oath-swearing, the wine was not drunk, ${ }^{77}$ but at ceremonies marking peace, it was: ${ }^{78}$ the women's apparent bibulousness thus has a proleptic quality offering the prospect of peace. Second, the kulix normally contained mixed wine, but here it is neat (197): ${ }^{79}$ they pervert sympotic practice, but in a good cause. Finally, placing the drinking-cup on the ground may recall the way satyrs on vases do this in a parody of normal mortal drinking: they either perform tricks over the cups or drink out of them while standing upside down. ${ }^{80}$

Two more positive filters are also evoked. The 'Lenaea vases' are a series of black- and redfigure stamnoi depicting women round a stamnos. ${ }^{81}$ The black-figure vases have a wider range of types of scene, often ecstatic; the red-figure have more dignified representations and a more standard scene. This usually shows, on one side, a mask of Dionysus, a stamnos on a table and women drawing wine from the stamnos or carrying it in skuphoi; and on the other, three women, often with thyrsus and pipes. The differences do not obscure the fact that the vases form a sequence. ${ }^{82}$ The image appears therefore to be Athenian, and though what exactly it represents is unclear, it is an example of women connected with wine in a dignified and sober context. The scene in Lysistrata is a mild parody of it. In place of the stamnos, we have a kulix (though the $\sigma \tau \alpha \mu v$ tov may evoke the former), ${ }^{83}$ and the women are for the most part restrained. On the 'Lenaea' vases, the skuphoi are never used for drinking, ${ }^{84}$ and Lysistrata's women do not appear actually to drink their wine, since the ololyge of the Old Women seizing the Acropolis intervenes (240): we expect an ololyge at sacrifices, but this one comes from without. It is true that there is no mask or representation of Dionysus (unless we count the

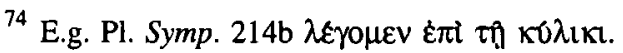

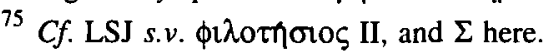

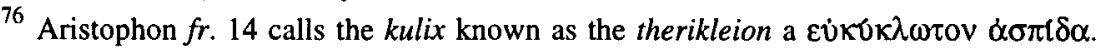

77 Cf. Il. 3.295-301; P. Stengel, Opferbräuche der Griechen (Leipzig and Berlin 1910) 186. Contrast the Scythians (Hdt. iv 70), whose actions perhaps colour the reception of the women's actions.

78 Burkert (n.51) 71.

79 J. Henderson, Aristophanes: Lysistrata (Oxford 1987) 93-4 suggests that the stamnos was an extravagance

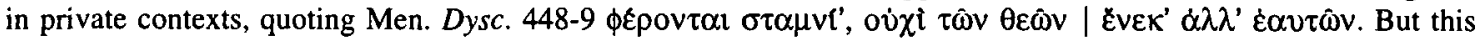
remark parallels Knemon's other complaints that people make offerings to the gods in ways that actually benefit themselves: he is not comparing private and public drinking.

${ }^{80}$ J.-L. Durand, F. Frontisi-Ducroux and F. Lissarrague, 'Wine: human and divine', in Bérard 126-7.

${ }^{81}$ Cf. A. Frickenhaus, Lenäenvasen (Berlin 1912). They were connected with the Anthesteria by M.P. Nilsson, JdI xxxi (1916) 327-8. Cf. A.W. Pickard-Cambridge, The dramatic festivals of Athens (rev. ed. by J. Gould and D.M. Lewis, Oxford 1988) 30-4; W. Burkert, Homo necans (London 1983) 230-8; B. Philippaki, The Attic stamnos (Oxford 1967) esp. xix-xxi; J.-L. Durand and F. Frontisi-Ducroux, RA (1982) 81-108.

82 Denied by J. de la Genière, MEFRA xcix (1987) 43-61 ( $c f$. Hamilton 134-8): the red-figure vases (unlike the black) are all by a few artists and only from Etruria. The claim that they represent purely Etruscan iconography would be stronger if there were confirmatory evidence from Etruscan art as in other cases she mentions.

${ }^{83}$ We do not in fact know what a stamnos looked like: the modern use of the word is conventional (Philippaki

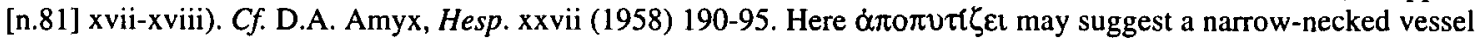
rather than the wider-necked 'stamnos'. Cf. K-A on Ar. fr. 546.

${ }^{84}$ Durand and Frontisi-Ducroux (n.81) 89. 
statue in the theatre), but this feature is sometimes absent from the vases: ${ }^{85}$ the stamnos is the feature that is always present, so the scene would have been recognisable without the mask. Interestingly, the Cleveland Dionysus, an Apulian bell-krater, ${ }^{86}$ also shows a kind of parody of this scene, apparently in a dramatic context: two satyrs in hairy costume, masks and comic phalloi, one with a skuphos, flank a large bust of Dionysus, with three figures (youth with thyrsus, satyr with pipes, and maenad) on the B side. This might support the notion that Lysistrata too is making comic use of a familiar ritual scene of decorous behaviour by women in the context of wine, to contrast with the usual suggestions of bibulousness. ${ }^{87}$

The second model is evoked by the oath. At the Anthesteria, on the night of Chytroi, the wife of the Archon Basileus entered into a sacred marriage with Dionysus. ${ }^{88}$ Before this, she administered an oath to the 'Honourable Women', in which they confirmed their purity and chastity. ${ }^{89}$ The comically reluctant oath of future chastity in the play thus has a serious analogue in the Anthesteria rite.

The dysfunctional nature of the city at this time is then demonstrated by the arrival of the Old Men with logs and vine-torches (308), in another parody of the komos. There is also a hint of the wedding komos: the Old Men get a 'wedding bath' (378), which, unlike the hieros gamos of the Anthesteria, marks the final split between the sexes. Thus, by parodying the symposium while drinking in a public yet relatively dignified manner around the kulix, and by refusing their husbands yet swearing an oath of chastity to benefit the city, the women occupy an ambiguous moral position, articulated in part by sympotic imagery.

Towards the end, these disordered sympotic scenes and marital disharmonies are finally replaced by more ordered and satisfactory circumstances: the Acropolis becomes the site of a 'symposium' (1225) for Athenians and Spartans together, and husband and wife are reunited. The restoration of male control is figured not just through their renewed political power and the restoration of family life, but also through the restoration of normal sympotic activity. Indeed, the symposium is proposed as the future model for Athenian diplomacy: sober, they are always looking for trouble and suspicious of the Spartans; drunk, they are $\sigma 0 \mu \pi \delta \tau \alpha \mathrm{r} \sigma 0 \phi \omega \tau \alpha \tau 01$ ('wisest symposiasts', 1227-35). Even if a symposiast sings the wrong scolion (1236-8), peace reigns. ${ }^{90}$ The symposium thus displaces war as the other means of diplomacy.

The play ends in a comastic way with singing and dancing to the accompaniment, not of the usual aulos or cithara, ${ }^{91}$ but of the Spartan bag-pipe (1242): a Spartan instrument accompany-

${ }^{85}$ E.g. Ox. Ash. M. 523, $A R V^{2} 621$ (41); NY Metr. Mus. no. 21-88-3, $A R V^{2} 1072$.

${ }^{86}$ Cf. The Bulletin of the Cleveland Museum of Art, January 1992; J. Green, Theatre in ancient Greek society (London 1994) fig. 3.23-4.

${ }^{87}$ Contrast perhaps Ar. fr. 364 for another, less reputable scene of (older) women: $\alpha$ kp $\alpha \tau o v \mid \Theta \alpha \sigma i o v$

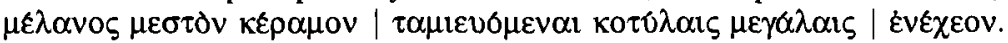

${ }^{88}$ Cf. Burkert (n.81) 232-7.

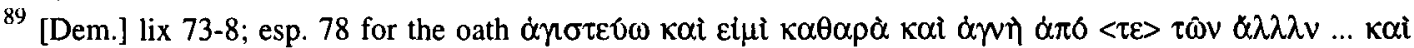
$\alpha \pi^{\prime} \alpha v \delta \rho \delta \varsigma \sigma 0 v o v \sigma(\alpha \varsigma$. The association with the Anthesteria is contested by S.M. Peirce, 'Representations of animal sacrifice in Attic vase-painting 580-380 BC' (Diss. Bryn Mawr College 1984), for which cf. Hamilton 53-6

${ }^{90}$ Exactly when it was right to sing 'Telamon' or 'Cleitagora' is not clear. 'Telamon' (cf. PMG 898-9) may

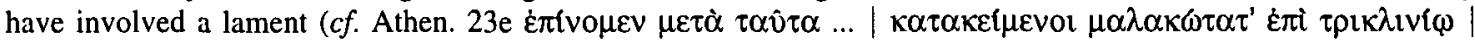

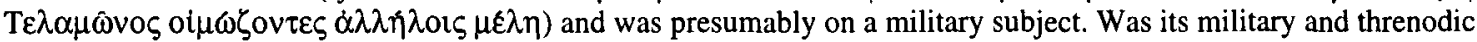

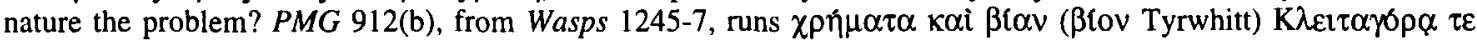
$\kappa \not \alpha \mu o l ~ \mu \varepsilon \tau \grave{\alpha} \Theta \varepsilon \tau \tau \alpha \lambda \omega \hat{v}$; if Tyrwhitt's emendation were correct, then 'Cleitagora' may have celebrated prosperity, which would suit the context in Lysistrata (the scolion is also referred to in Ar. fr. 271 and Cratinus fr. 254). Cleitagora on a vase, D.M. Robinson, AJA lx (1956) 21-2. An ideological dispute over the appropriate scolion to sing appears also in Ar. fr. 444. Alternatively, the mistake may lie in singing the wrong words to the tune struck up: A.H. Sommerstein, Aristophanes: Lysistrata (Warminster 1990) 219 (with Cratinus fr. 254).

${ }^{91}$ Cf. H.Herm 481; [Hsd.] Scut. 281. 
ing a sympotic revel in Athens signifies the new unity. ${ }^{92}$ The komos thus marks the final triumph of peace over war: a symposium and subsequent komos were a traditional celebration of a victory. ${ }^{93}$ Once again, the women have a role, providing food from their baskets (1182-4) and sharing in the dancing. ${ }^{94}$ Though symposia and komoi were regular after weddings, ${ }^{95}$ and husband and wife have just been reunited, it is unusual for citizen women to join in this comastic dancing, ${ }^{96}$ but appropriate perhaps for the ending of a play of reconciliation brought about by female initiative and inaugurated by wine. Disordered female sympotic actions and a violent komos early in the play are replaced by more acceptable and peaceable ones. In a way, in 411 women at the komos would have been no more strange than Athenian and Spartan together at the symposium. ${ }^{97}$ These sympotic impossibilities tacitly reflect the impossibility of the play's action.

\section{Acharnians $^{98}$}

Here Amphitheus' treaty-wine inaugurates the plot, and Dicaeopolis' words on accepting the thirty-year treaty are those of a man receiving the cup at a symposium $(196,199):{ }^{99}$

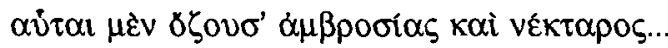

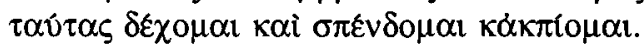

(These smell of ambrosia and nectar ... I receive them, and pour a libation and drink them down.)

Early in the play, wine effects a double characterisation of the Acharnians, which foreshadows a similar representation of Dicaeopolis at the end. The Spartans' trampling of their vines (233) justifies their desire for war, but their attack on Dicaeopolis' celebration of the Rural Dionysia puts them in a negative light. Their violent reaction when they smell (179) Amphitheus' wine recalls the Centaurs, whom the smell of the miraculously aged wine given by Pholus to Heracles caused similarly to break up a symposium with their tree-branches. ${ }^{100}$

As in Knights, a sympotic opening is followed by three main sympotic segments, in which the subsequent progress of the victory of peace over war is charted. The process starts when Dicaeopolis discomfits Lamachus (582-6):

\footnotetext{
${ }^{92}$ The appeal to Mv $\alpha \mu \delta v \alpha(1248)$ recalls the sympotic use of remembrance of past events: $c f$. Rösler (n.50); M. Simondon, La mémoire et l'oubli dans la pensée grecque (Paris 1982).

${ }^{93}$ Cf. e.g. Pindar's epinicians as komoi (C. Carey, AJP cx [1989] 545-65, esp. 549); Agathon's victory in Pl. Symp. and [Dem.] lix 33; also Alexander's seven-day komos after his Indian victories at Diod. xvii 106.1; Plut. Alex. 67.1 .

94 The staging and allocation of parts at the end is highly problematic, but if Sommerstein's (persuasive) arguments in favour of Lysistrata's giving the commands in $1273 \mathrm{ff}$. are right, we would have a scene with her in charge parallel to the oath-swearing at the start: $c f$. Sommerstein (n.90) 221-2.

${ }^{95}$ Cf. Daremberg and Saglio (n.28) 1597.

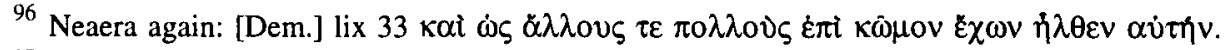

${ }^{97}$ For Spartan hostility to the symposium, cf. Pl. Laws $1.637 \mathrm{a}-\mathrm{b}$.

98 Cf. also Levine (n.7) 194-5 and R. Scaife, GRBS xxxiii (1992) 25-35.

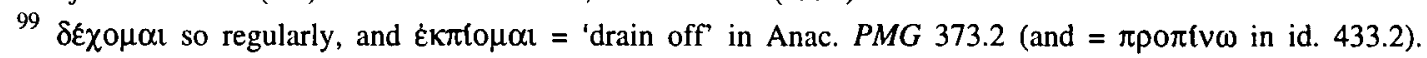
Curiously, there are echoes of the Cyclops' reaction to Odysseus' miraculous wine: compare ó $\delta \varepsilon \delta \varepsilon \kappa \tau o ~ \kappa \alpha i ~ \varepsilon k \pi \imath \varepsilon v$

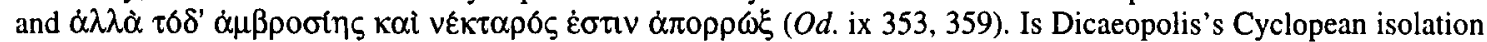
and selfishness thus foreshadowed at this crucial moment, and does his opposition to the one-eyed Pseudartabas hide a potential similarity?

${ }^{100}$ Diod. iv 12; the Acharnians use equally primitive stones.
} 


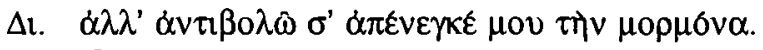

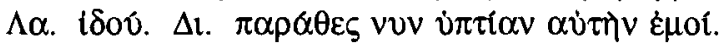

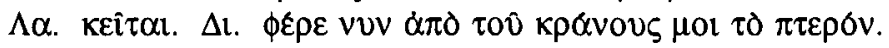

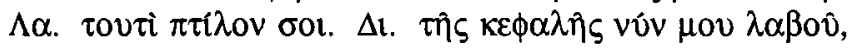

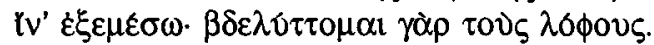

(Di. Please, take away your bug-a-boo. La. There you are. Di. Turn it upside down. La. Upside down it is. $D i$. Now take the feather from your helmet. $L a$. There you are, a feather. Di. Right, take hold of my head so that I can be sick-I hate crests.)

Symposiasts being sick into a bowl whilst a slave or hetaira holds their heads are common on sympotic vessels, and the feather is regularly mentioned as a means of procuring vomiting, ${ }^{101}$ as in Theopompus' list of sympotic paraphernalia: ${ }^{102}$

$\sigma \pi \delta \gamma \gamma \sigma \varsigma, \lambda \varepsilon \kappa \alpha v \eta, \pi \tau \varepsilon \rho \sigma v \lambda \varepsilon \pi \alpha \sigma \tau \eta \pi \alpha<v v \pi v \kappa v \eta$,

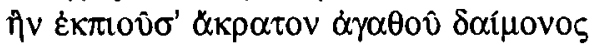

$\tau \varepsilon \tau \tau \xi \xi \kappa \lambda \lambda \alpha \delta \varepsilon \hat{\text {. }}$

(sponge, bowl, feather, copious drinking-cup, from which she drinks neat wine with an 'agathou daimonos' and sings like a cicada.)

As in Peace, the use of weapons for the body's ease represents a satisfying initial triumph of the symposium over the play's early violence and inaugurates Dicaeopolis' new world.

After the expulsion of the anti-sympotic sycophant Nicarchus, the $\kappa \rho \alpha \tau \eta \rho \rho \kappa \alpha \kappa \hat{\nu}, \tau \rho \iota \pi \tau \eta े \rho$

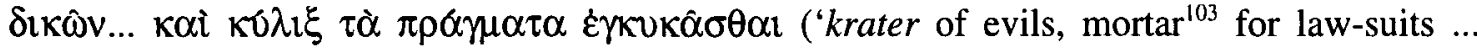
and cup for stirring up trouble', 937-9), the Chorus celebrates Dicaeopolis' new world thus (979-87):

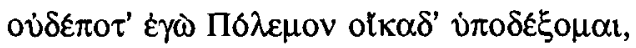

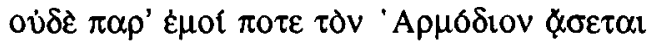

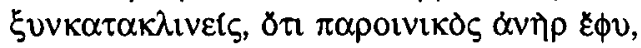

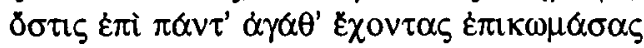

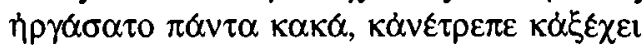

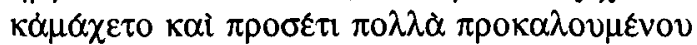

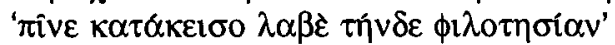

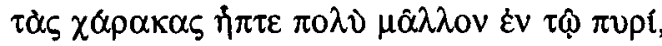

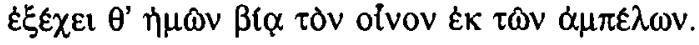

(I will never receive Polemus into my house, nor will he ever sing the 'Harmodius' scolion as he lies beside me, because he is a violent drunkard. He came on a komos to us when we had plenty, and behaved abysmally: he turned things over, scattered them about, and brawled, and when I invited him more than once to 'drink, lie down, take this loving-cup', he started to burn the vine-props in the fire all the more, and spill the wine violently from our vines).

The effect of war on Greece is represented in sympotic terms, and Polemus' banishment from society is reflected in his banishment from the symposium for refusing to respect its decorum or to perform its traditional acts. Polemus' burning of the vine-props and destruction of the wine

${ }^{101}$ Cratinus frr. 271, 292; Plato Com. fr. 201; Nicander, Alex. 362.

${ }^{102} \mathrm{Fr} .41$; see passages quoted by Rogers on Ach. 584.

${ }^{103} \tau \rho t \pi \tau$. $\rho$ also means a vat into which wine is run (Isaeus fr. 24; Pollux vii 151). 
recalls the Spartans complained of earlier. ${ }^{104}$

Finally, there is a reprise of the scene with Lamachus, when he and his shield are once again summoned to repel a Boeotian invasion, while Dicaeopolis is called to dinner at the Choes festival by the priest of Dionysus (1071 ff.). Dicaeopolis is to bring a kiste of food and his chous for the drinking-competition, the rest 'couches, tables, cushions, coverlets, garlands, myrrh, tragemata, cakes, hetairai' (1090-3) are all provided. A long stichomythic scene follows, during which each makes suitable preparations, Lamachus for war, when $\chi \varepsilon 1 \mu \varepsilon p 1 \alpha \tau \grave{\alpha} \pi \rho \alpha \eta \mu \alpha \tau \alpha$ ('it's

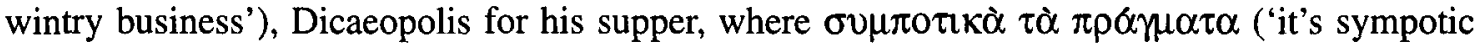
business', 1141-2). The very form of this scene, in which one character caps the words of another, has its analogue in similar sympotic practice. ${ }^{105}$ The subsequent contrast between the wounded Lamachus, supported by two attendants, and Dicaeopolis, supported by two hetairai, makes the point of the symposium's triumph even more firmly. We thus end again with a komos,

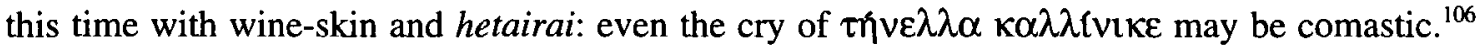

The treatment of Lamachus' shield is again important for the fuller meaning of this scene. It is repeatedly said to be decorated with a Gorgon, a common shield-emblem which is obviously fitting for a man symbolising war, and may actually have adorned the shield of Lamachus. ${ }^{107}$ Its function was to terrify and so render ineffective the enemy soldier. ${ }^{108}$ Dicaeopolis' disdain for the power of the Gorgon on the shield, which earlier inspired at least mock fear but now provokes only laughter, shows how the horror of war's face has been exorcised in Dicaeopolis' world of peace, much as Polemus has been banned from violent disruption of the Chorus' symposium. Lamachus' grim martial Gorgon is treated as if it were one of the very many sympotic representations of this figure whose sheer repetition neutralised its terrifying force: 'virtually all representations ... exploit ... the essential ambivalence of the grimace that alternately arouses fear and laughter, thus providing the Greeks in their daily life with the visible manifestation of a horror that has been tamed'. ${ }^{109}$

Though this scene can be thus decoded as symbolising the symposium's triumph over the threats of war, it can also be interpreted in another way. The Gorgon-head is one of those rare cases, along with e.g. Dionysus and the satyrs, where a figure looks out of the drinking-vessel. Such figures have been plausibly interpreted as representing the 'Dionysiac gaze', which looks at the drinker and questions him about his behaviour under the influence of the wine. ${ }^{110}$ Thus Dicaeopolis' triumph over the controlling power of the Gorgon's Dionysus-like stare, however attenuated that power may have been in the symposium, could be interpreted as effective freedom from the constraints on behaviour imposed by the symposium.

The point is given greater specificity in 1128-31:

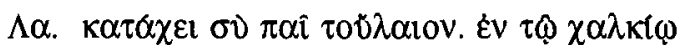

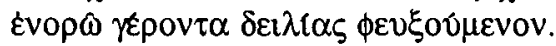

${ }^{104}$ Furthermore, as L. Edmunds, YCS xxvi (1980) 20 points out, 'since Aristophanes... has defined comedy as wine-song ( $c f .499-500$ ), the characterization of War as the enemy of wine ... implies ... that War is the enemy of the festival, of the sacral basis of ... peace'.

105 Cf. Wasps 1222 ff.; B.M. Palumbo Stracca, SIFC xiv (1996) 35-47.

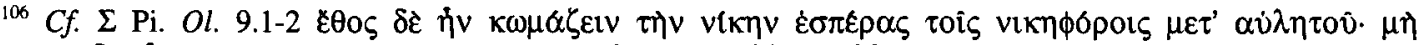

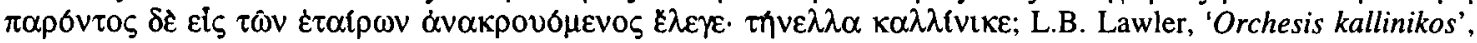
TAPA lxxix (1948) 254-67.

${ }^{107}$ So $\Sigma$ Ach. 574; cf. Peace 474.

${ }^{108}$ Cf. J.E.M. Dillon, 'The Greek hero Perseus: myths of maturation' (Diss. Oxford 1989) 71-93; J.-P. Vernant, 'Death in the eyes: Gorgo figure of the Other', in Mortals and immortals: collected essays (F.I. Zeitlin [ed.], Princeton 1990) 111-38 (137-8); cf. 'In the mirror of Medusa', ibid. 141-50.

${ }^{109}$ Frontisi-Ducroux in Berard 159-60; $c f$. Vernant (n.108) 149.

${ }^{110} C f$. e.g. Frontisi-Ducroux in Bérard 151-65. 


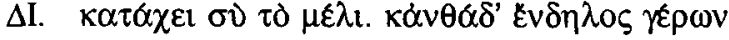

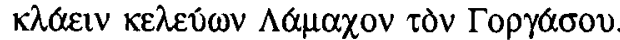

La. Boy, pour on the oil. In the bronze ${ }^{111}$ I see an old man who'll be on a charge of desertion. Di. And you pour on the honey. Here one can clearly see an old man telling Lamachus son of Gorgasos to go hang.)

The symposium tests the drinker's nature: wine was a 'mirror' of his nature, not just by what it caused him to reveal, but also by the way it and the vessels that held it offered him a range of possible other identities. ${ }^{112}$ The same idea appears in the games of comparisons played. ${ }^{113}$ So in this passage, we have two reflected images (not in wine, it is true, but reflection is the key idea), of a man who is either a shirker or happily freed from the demands of generals, that is, from a citizen's duties. Both characterisations are possible, even if Lamachus exaggerates in threatening with prosecution for desertion one who has not been called up: Dicaeopolis' carefree sympotic enjoyment is little help when the Boeotians attack. War does not stop because someone decides it would be nice if it did: barring Polemus from a symposium is easier in imagery than reality, and war against invaders has its part to play if one wishes to be safe to enjoy the symposium.

This dual characterisation of Dicaeopolis is confirmed in the final scenes, where we seem to have a double appearance of sympotic imagery. First, there is the Priest of Dionysus' symposium, ${ }^{114}$ which is clearly different from the Choes drinking-competition that features at the end of the play and in which Dicaeopolis has been victorious. This competition was itself a kind of 'parody' of a symposium, at which each man sat alone, in silence, without a garland and with his own chous. ${ }^{15}$ We have therefore a normal celebratory symposium juxtaposed with one constructed to enable the city to accept the polluted outcast Orestes. ${ }^{116}$ There are thus two possible views of Dicaeopolis: as the triumphant champion of peace welcomed back as a example to the city he abandoned, and as the man whose actions, like Orestes', put him beyond the pale. Is the city's welcome of this man to its symposia the result of the realisation that he was right, of a new attitude of forgiveness, or a further example of its earlier willingness to entertain those who only appear to have the city's interests at heart?

The ambiguities in the sympotic imagery of this play mirror similar problems of deciding how we are to read Dicaeopolis.

111 'Lamachus oils the boss of his shield to make it shine more', ( $\left.\Sigma^{\text {vet+Tr }} 1128\right) . \chi \alpha \lambda \kappa$ fov is not however so used elsewhere, meaning usually 'a pot or cauldron'. Pollux quotes this passage for the meaning 'metal reflector (of

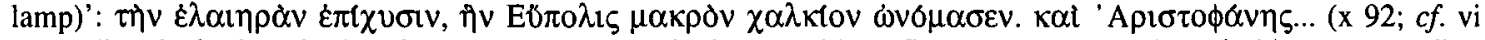
$110=$ 'bowl of a kottabos'); $c f$. Xen. Symp. 7.4 on the lamp and its reflector). However, since, in his corresponding lines, Dicaeopolis pours honey on his cake and this was earlier the counterpart of the shield (1124-5), the oil must be poured on the shield.

${ }^{112}$ E.g. 'the satyr ... presents man with the image of his hidden desires, of the savagery he holds in check, the exhibition of a truth quite different from his official identity' (Frontisi-Ducroux in Bérard 156).

${ }^{113}$ Cf. n.52 above. I know, however, of no texts where reflections in wine are discussed thus. Catoptromancy, for the first time in history, is another theme here: $c f . \Sigma^{\mathrm{vet}} 1128$ and A. Delatte, La catoptromancie grecque et ses dérivés (Liege and Paris 1932) 133-5.

${ }^{114}$ If it does represent an event at the Choes, it is probably a private continuation of the drinking competition: cf. Hamilton 12-13; G. van Hoorn, Choes and Anthesteria (Leiden 1951) 30-3.

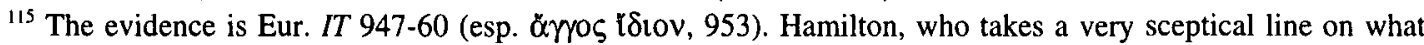
we can know of the Anthesteria, suggests that this aetiology is the creation of Euripides (15), in part because the gloomy nature of the $I T$ rite contrasts with that of the celebratory nature of the comic version. I see no problem, however, in a rite with different aspects that different genres could evoke for different purposes. 958-60 also seem odd if Euripides has made the connection up. $C f$. on the festival Burkert (n.81) 213-47; Pickard-Cambridge (n.81) 1-25; N. Robertson, HSCP xcv (1993) 197-250.

${ }^{116}$ Cf. A.M. Bowie 35-9. 
A female herald summons the citizens to the lottery and announces the preparations: there are tables, couches covered with skins and blankets, kraters being mixed, unguent-sellers at hand, fish, hare, cakes, soup and tragemata in preparation, garlands being woven (834-52). As Schmitt-Pantel points out, 'ce repas ... bien loin d'être à l'image d'un banquet civique traditionel, a tous les caractères du banquet privé ... Les aliments proposés dans ce syssition sont ceux des repas privés ... les modes de cuisson sont ceux de la cuisson domestique'.119 Praxagora's new world is thus essentially a private symposium on a city-wide scale. The Orphics, in Plato's somewhat tendentious account, promised such a permanent symposium to

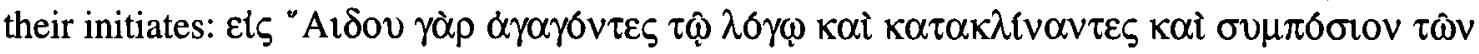

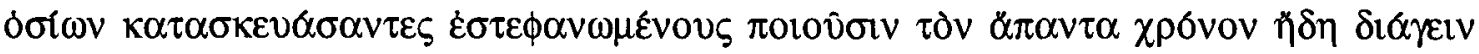

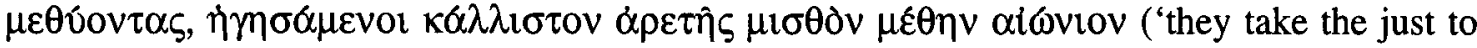
the other world and provide them with a banquet of the Blest, where they sit for all time carousing with garlands on their heads, as if virtue could not be more nobly recompensed than by an eternity of intoxication'). ${ }^{120}$

They did not however balance this offer with any such catch as Praxagora's sexual legislation, which as much as the permanent symposium marks the strangeness of this new world. The effects of this legislation are shown alongside the sympotic pleasures. Between the Heraldess' announcement and the Serving Girl's expressions of delight at the excellence of the wine (1123), there is a grim scene in which a young man on a komos ${ }^{121}$ is deprived of his young girl-friend by increasingly unappetising old women, and finally exits giving instructions for his funeral. ${ }^{122}$ The ending is thus a disturbing mixture both of fantasy leading to a utopian world of unity and self-indulgence, and of a sexual code likely to lead to a 'land of Oedipuses' (1042). As at the end of Wasps, the symposium triumphs, but again it is not clear that this is necessarily beneficial to everyone. Here then the symposium functions as an ambiguous signifier, offering generalised pleasure, but with a sting in the tail, that is, the komos, for those expecting the traditional pleasures associated with it.

The ending of the play and how far it is bitter or ironic has been much discussed, and here is not the place to discuss that matter in full. ${ }^{123}$ Aristophanes certainly emphasises the grim aspects of the seduction of the Young Man, but a consideration of the scene in terms of the symposium may prevent one over-emphasising its unpleasantness. The end of the play essentially shows how the logic of the reversals involved in the political and sexual conversion of Athens entails comparable reversals in the symposium, which generate the comedy of the scene. The symposium cannot become the medium of public political life in the new Athens without changing its essential nature to accommodate new demands from the mature women now in political control. Symposia now take place in public not private, citizen women not hetairai provide sexual and other services, the komos ends not in the house of attractive youth but of terrifying old age. The real symposium is an essentially male-dominated institution; mature males were privileged over younger and especial licence was apparently given to men

$119229-30$.

${ }^{120} \mathrm{Pl}$. Rep. 2.363c-d (tr. Cornford); cf. P. Foucart, Des associations religieuses chez les Grecs, thiases, éranes, orgéons (Paris 1873) 153-77.

${ }^{121} C f . \pi \varepsilon \pi \omega \kappa \omega \zeta$ (948), $\delta \hat{\alpha} \delta^{\prime} \varepsilon \chi \psi \omega \nu$ (978). Cf. Bowra (n.55).

${ }^{122}$ A comparable scene of young man on komos and old lover appears near the end of Plutus (1040 ff.), but the very homely ending of that play makes no use of other sympotic imagery.

${ }^{123}$ Cf. esp. S. Saïd, 'L'assemblée des femmes: les femmes, l'économie et la politique', in D. Auger, M. Rosellini and S. Saï, Aristophane, les femmes et la cité (Fontenay-aux-Roses 1979) 33-69 (abbr. tr. in E. Segal [ed.], Oxford readings in Aristophanes [Oxford 1996] 282-313); A.H. Sommerstein, CQ xxxiv (1984) 314-33; K.S. Rothwell Jr., Politics and persuasion in Aristophanes' Ecclesiazusae (Leyden 1990); L.K. Taaffe, Aristophanes and women (London 1993) 124-33; D. Konstan and M. Dillon, AJP cii (1981)382. 
of advanced age; ${ }^{124}$ the komos offered opportunities for self indulgence, especially it seems for the younger members. All of this must now change, so that women and especially older women have their due: as in Lysistrata, sexual and political control is accompanied by sympotic control, as Praxagora becomes the city's symposiarch.

One might wonder too whether the end of Ecclesiazusae does not reflect upon comedy's use of this convenient closural technique and the implied assumption that the symposium is an unproblematic metaphor for idealised existence. Lysistrata seemed aware of the improbability of its final symposium, and here too the symposium is proposed as the structure of a utopia, but its implementation acknowledges the problems involved. The institutions of the symposium seem inadequate: reversed to fit the new political reality, they may offer a vision of endless vinous bliss but also involve sexual inversions that threaten the fabric of society. The symposium cannot become a model for society without changing itself to fit its new function and context, and these changes render it in many ways unlike its original form.

It was the function of the symposium under the gaze of Dionysus to pose questions to the drinker about his behaviour and nature. Comedy too posed questions to the audience in a similar way, ${ }^{125}$ and used grotesque masked figures as did the sympotic vessels. ${ }^{126}$ At the same time, Comedy may be said, especially in Ecclesiazusae, to put questions to the symposium itself. The equality of drinkers round the krater may not be a bad model for a democracy and sympotic activity may have its attractions, but essentially symposia are private celebrations which, while they may be employed to symbolise a political ideal in various ways, do not offer a practical solution to unsatisfactory political circumstances. Dionysus may pose questions to the city through comedy, but his characteristic symposia, so often employed by Dionysiac comedy, do not necessarily give answers.

The Queen's College, Oxford

A.M. BOWIE

${ }^{124}$ Cf. Xenoph. 1.17-18.

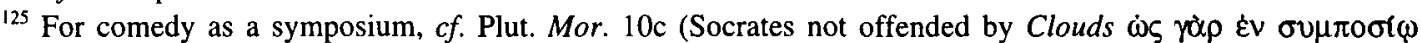

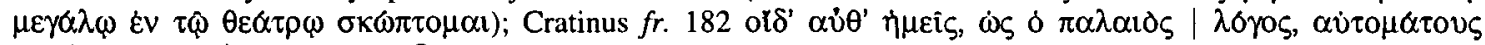

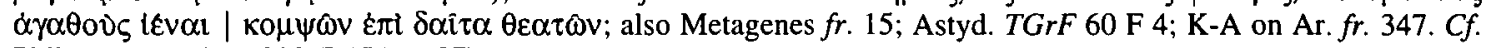
Philochorus FGrH 328 F 171 (n.27).

${ }^{126}$ Cf. A.M. Bowie 14-17. 